\title{
DINAMIKA PSIKOLOGIS ANAK PEREMPUAN KORBAN KEKERASAN SEKSUAL INCEST: SEBUAH STUDI KASUS
}

\section{PSYCHOLOGICAL DYNAMIC OF CHILDREN AS VICTIM OF SEXUAL INCESTUOUS: A CASE STUDY}

\author{
Sulastri $^{1}$, Any Nurhayaty ${ }^{2}$ \\ Fakultas Psikologi Universitas Muhammadiyah Lampung \\ sulastri2270@gmail.com
}

Received: $4^{\text {th }}$ January 2021; Revised: $21^{\text {st }}$ Januari 2021; Accepted: $5^{\text {th }}$ February 2021

\begin{abstract}
Sexual violence against children is increasingly happening. No exception during Covid19 pandemic whose victims are both boys and girls. One type of sexual violence against children includes incest (inbreeding). Incest is a sexual relationship or sexual activity between closely related individuals, where marriage between them is prohibited by law or culture. Research related to psychological dynamics of incest victims still need exploration. This study aims to obtain a picture of the psychological dynamics of children victims of sexual incestuous violence. Research main goal is to become a reference source for providing interventions for child victims of incest, both preventive and curative. The method used is qualitative with a case study model, the selection of methods is done to fully understand the subject's point of view. The research subjects were child victims of incest sexual violence. Collecting data using in-depth interview and observation techniques. The results showed that the dynamic function of psychology between cognitive aspects, emotional aspects and interpersonal relationships are interrelated with one another, resulting in changes in quiet behavior, being afraid of meeting father and obstructing communication with mother. Get support from friends, grandmothers and older siblings, so that the subject can change the situation to positive things into positive thinking and positive behavior.
\end{abstract}

Keywords: Children, Psychological Dynamics, Sexual Violence, Victims, Incest 


\begin{abstract}
ABSTRAK
Kekerasan seksual terhadap anak semakin marak terjadi, dan tidak terkecuali disaat pandemi covid-19 berlangsung, yang menjadi korban baik anak laki-laki maupun anak perempuan. Salah satu jenis kekerasan seksual terhadap anak diantaranya adalah incest (hubungan sedarah). Incest adalah hubungan seksual atau aktivitas seksual antara individu yang mempunyai hubungan dekat, yang mana perkawinan antar mereka dilarang oleh hukum maupun kultur. Penelitian mengenai dinamika psikologi korban incest masih sangat minim. Penelitian ini bertujuan untuk mendapatkan gambaram dinamika psikologis anak korban kekerasan seksual incest. Diharapkan dapat menjadi salah satu sumber acuan pemberian intervensi bagi anak korban incest, baik preventif maupun kuratif. Metode yang digunakan adalah kualitatif dengan model studi kasus, pemilihan metode dilakukan untuk memahami secara utuh dari sudut pandang subjek. Subjek penelitian adalah anak korban kekerasan seksual Incest. Pengambilan data menggunakan teknik wawancara mendalam dan observasi. Hasil penelitian menunjukkan bahwa fungsi dinamika psikologi antara aspek kognitif, aspek emosi dan hubungan interpersonal saling mempunyai keterkaitan satu sama lainnya, sehingga terjadi perubahan perilaku yang pendiam, menjadi takut bertemu dengan Ayah dan terhambatnya komunikasi dengan Ibu. Mendapatkan dukungan dari sahabat, nenek dan kakak, sehingga subjek dapat merubah keadaan ke hal-hal yang positif menjadi berpikir positif dan berperilaku positif.
\end{abstract}

Kata Kunci: Anak Perempuan, Dinamika Psikologis, Kekerasan Seksual, Korban, Incest

\title{
PENDAHULUAN
}

Kasus kekerasan seksual setiap tahunnya semakin meningkat dan selalu yang menjadi korban adalah perempuan dan anak, selain itu, bentuk relasi pelaku-korban, dan motivasi, serta cara melakukannya juga beragam. Laju pertambahan korban tidak dapat dibendung lagi. Pemerintah, Lembaga Sosial Masyarakat, Organisasi dan Instansi yang konsentrasi programnya pada anak korban kekerasan secara umum termasuk di dalamnya kekerasan seksual, sudah melakukan upaya untuk menekan jumlah kekerasan. Namun upaya yang dilakukan tidak mempunyai arti yang bermakna, dengan buktinjumlah anak korban kekersan seksual kian bertambah. Dengan adanya kondisi ini, sehingga tIndonesia mencanangkan Darurat kekerasan terhadap anak.

Hasil laporan data pada perempuan dan anak Dinas Pemberdayaan Perempuan dan Anak (PPPA) Provinsi Lampung, berdasarkan SIMFONI-PPA tahun 2016 - 2020 bahwa jumlah korban kekerasan tahun 2015 adalah 153 orang, tahun 2017 adalah 148 orang, tahun 2018 adalah 154 orang, tahun 2019 adalah 251 orang dan tahun 2020 berjumlah 251 orang. Jumlah ini tentunya bukan jumlah 
secara keseluruhan karena kasus kekerasan seksual di analogikan sebagai fenomena gunung es, artinya yang muncul ke permukaan hanya sedikit, sedangkan yang tidak muncul dapat dikatakan lebih banyak lagi. (Simfoni Dinas PPPA Provinsi Lampung, 2020).

Hasil tangkapan KPAI bahwa jumlah kasus kekerasan dalam bentuk Incest banyak terjadi di berbagai provinsi. Provinsi Lampung pada tahun 2018 menjadi sorotan publik dengan adanya kasus incest dengan pelaku ayah kandung, kakak kandung dan adek kandung, dan dengan kondisi korban yang mengalami keterbelakangan mental. Dengan kondisi iini tentunya besar sekali dampaknya bagi anak sebagai korban, karena faktor kedekatan dan kemungkinan selalu akan bertemu dengan pelaku, sehingga akan mengganggu dinamika psikologis anak. Dinamika psikologi adalah proses dan suasana kejiwaan internal individu dalam menghadapi dan mensolusi konflik yang dicerminkan oleh pandangan atau persepsi, sikap dan emosi, serta perilakunya. Dikarenakan akan membutuhkan waktu dalam pemulihannya, karena kondisi psikologis yang terkena dampak traumatis. Seperti halnya menurut (Noviana, 2015) bahwa dampak kekerasan seksual terhadap anak cenderung menimbulkan dampak traumatis baik pada anak maupun pada orang dewasa

Incest adalah hubungan seksual atau aktivitas seksual antara individu yang mempunyai hubungan dekat, yang mana perkawinan antar mereka dilarang oleh hukum maupun kultur. Incets biasanya terjadi dalam waktu yang lama dan sering menyangkut suatu proses terkondisi (Huraerah, 2012). Menurut Mulyadi (dalam Uyun, 2011) korban kekerasan seksual termasuk incest akan mengalami trauma atas apa yang telah terjadi dalam hidupnya, sehingga akan mempengaruhi kehidupan anak dimasa depan. Dampak yang ditimbulkan dari kekerasan seksual pada anak seringkali meninggalkan bekas traumatis yang sulit dihilangkan, mereka merasa dendam, takut menikah,merasa rendah diri, dan berbagai trauma lain akibat kekerasan seksual yang mereka alami.

Anak adalah seseorang yang belum berusia 18 (delapan belas) tahun termasuk anak dalam kandungan. Sedangkan pengertian Perlindungan Anak pada pasal 2 adalah segala kegiatan untuk 
menjamin dan melindungi anak dan hak-haknya agar dapat hidup, tumbuh, berkembang, dan berapstisipasi, secara optimal sesuai dengan harkat dan martabat kemanusiaan, serta mendapat perlindungan dari kekerasan dan diskriminasi” (KPAI, 2018).

Noviana (2015) menyatakan bahwa kekerasan seksual merupakan jenis penganiayaan yang biasanya dibagi dua dalam kategori berdasarkan identitas pelaku, yaitu:

a) Familial Abuse

Yang termasuk familial abuse adalah incest, yaitu kekerasan seksual dimana pelakunya adalah anggota masih dalam hubungan darah, menjadi bagian dalam keluarga inti korban. atau orang.

b) Extra Familial Abuse

Kekerasan seksual extra familial abuse adalah kekerasan yang dilakukan oleh orang lain yang tidak termasuk dalam anggota keluarga korban, atau bisa dikatakan orang lain.

Klasifikasi kekerasan seksual menurut Resna dan Dermawan (dalam Huraerah, 2012) terdapat 3 macam, yaitu:

a) Perkosaan. Pelaku tindakan perkosaan ini biasanya pria. Terjadi biasanya pada saat di mana pelaku lebih dulu mengancam dengan memperlihatkan kekuatannya kepada anak. Apabila terdapat kasus pemerkosaan dengan kekerasan pada anak, akan merupakan suatu resiko terbesar karena penganiayaan sering berdampak emosi tidak stabil.

b) Incest, didefinisikan sebagai suatu hubungan seksual atau aktivitas seksual antara individu yang mempunyai hubungan dekat, yang mana perkawinan di antara mereka dilarang oleh hukum maupun kultur. Biasanya terjadi dalam waktu yang lama dan sering menyangkut suatu proses terkondisi.

c) Eksploitasi. Termasuk seksual yang meliputi prostitusi dan pornografi, dan hal ini cukup unik karena sering meliputii suatu kelompok secara berpartisipasi. 
Richard (dalam Huraerah, 2012) mengemukakan bahwa kekerasan terhadap anak (child abuse) terjadi akibat kombinasi dari berbagai faktor, yaitu:

\section{Pewarisan Kekerasan Antar Generasi (intergenerational transmission of violence)}

a) Banyak anak belajar perilaku kekerasan dari orangtuanya dan ketika tumbuh menjadi dewasa mereka melakukan tindakan kekerasan kepada anaknya.

b) Stres Social (social stress)

c) Stres yang ditimbulkan oleh berbagai kondisi sosial meningkatkan risiko kekerasan terhadap anak dalam keluarga.

d) Isolasi Sosial dan Keterlibatan Masyarakat Bawah

e) Orangtua dan pengganti orangtua yang melakukan tindakan kekerasan terhadap anak cenderung terisolasi secara sosial.

f) Struktur Keluarga

g) Tipe-tipe keluarga tertentu memiliki risiko yang meningkat untuk melakukan tindakan kekerasan dan pengabaian kepada anak.

Dinamika Psikologi adalah proses dan suasana kejiwaan internal individu dalam menghadapi dan mensolusi konflik yang dicerminkan oleh pandangan atau persepsi, sikap dan emosi, serta perilakunya (Nursalim dan Purwoko, 2009). Sedangkan menurut Refia dan Purwoko (2014) bahwa dinamika psikologis adalah proses yang terjadi dalam kejiwaan individu ketika menghadai dan menyelesaikan konflik, mencakup persepsi, sikap dan perilaku.

Komponen dalam diri manusia yang berpengaruh dan membentuk perilaku dalam kehidupan sehari-hari adalah yang berkaitan dengan dinamika psikologis, yaitu sebagai berikut:

a) Komponen Kognitif, komponen perseptual yang berkaitan dengan pengetahuan, pandangan dan keyakinan.

b) Komponen Afektif, komponen emosional yang berhubungan dengan rasa senang atau tidak senang terhadap objek perilaku. 
c) Komponen Konatif, komponen perilaku (action component) yaitu komponen yang berhubungan dengan kecenderunagn bertindak terhadap objek.

Ketiga komponen di atas selalu berlangsung bersama-sama dan selalu runtut. Fungsi kognisi, emosi dan konasi itu bisa berlangsung lancar dan harmonis, namun tak jarang disertai banyak konflik, seperti konflik diantara pikiran, perasaan dan kemauan yang saling berbenturan atau berlawanan (Kartono, 1996).

Proses kehidupan manusia selalu diikuti oleh ketiga aspek psikologis yaitu aspek kognitif, aspek emosional atau perasaan dan aspek kemauan atau hubungan interpersonal. Aspek kognitif berkaitan dengan persepsi, ingatan, belajar, berpikir dan problem solving dan aspek afektif berkaitan dengan emosi atau perasaan dan motif. Sedangkan aspek konatif berhubungan dengan perilaku seseorang yang meliputi hubungan interpersonal dan intrapersonal (Walgito, 2017)

Berdasarkan uraian di atas, maka peneliti berinisiatif untuk melakukan penelitian dengan melakukan analisis dan studi kasus tentang dinamika psikologis anak korban kekerasan seksual incest. Sedangkan mengetahui bagaimana dinamika psikologis anak korban adalah menjadi tujuan pada penelitian ini.

\section{METODE PENELITIAN}

Metode yang digunakan dalam penelitian ini adalah menggunakan metode kualitatif, karena permasalahan berhubungan dengan manusia yang secara fundamental tergantung pada sebuah pengamatan. Menurut Creswell (2012), penelitian kualitatif merupakan metode-mtode untuk mengeksplorasi dan memahami makna yang oleh sejumlah individu atau sekelompok orang dianggap berasal dari masalah sosial atau kemanusiaan. Menggunakan metode kualitatif dirasa sangat sesuai karena mampu menjawab tujuan penelitian yaitu mengetahui dinamika psikologis atau latar belakang anak korban kekerasan seksual. Sehingga pendekatan yang digunakan adalah studi 
kasus subjek dengan kriteria korban kekerasan seksual incest usia 14-15 tahun dan pelaku ayah tiri. Penelitian dengan pendekatan studi kasus dimana peneliti melakukan eksplorasi secara mendalam terhadap program, kejadian, proses, aktivitas, terhadap satu atau lebih orang (Sugiyono, 2018).

Teknik pengumpulan data yang digunakan dalam penelitian ini adalah wawancara (interview) dan observasi dengan pengamatan langsung di lokasi penelitian. Teknik analisis data dalam penelitian kualitatif dilakukan dengan pengumpulan data, reduksi data, penyajian data, kesimpulan dan verifikasi. Dalam menguji keabsahan data peneliti menggunakan teknik triangulasi metode dan triangulasi sumber. Sebagai unit analisis dari penelitian ini adalah dinamika psikologis anak korban kekerasan seksual incest yang usia 15 tahun.

\section{HASIL PENELITIAN}

Subjek berinisial $\mathrm{KH}$ berusia 15 tahun beragama Islam dan berpendidikan terakhir SMP. Terjadinya kekerasan saat subjek memutuskan untuk berkumpul lagi dengan ibu yang sudah menikah lagi. Ibu bekerja tidak menetap, yaitu buruh nyuci gosok dan membantu masak jika tetangga mendapatkan pesanan. Ayah tiri bekerja sebagai satpam dengan kerja 2 shift, yaitu malam dan siang. Jika ibu subjek bekerja dan ayah kerja shift malam, maka dirumah hanya subjek dan ayah tirinya, dan kesempatan inilah yang menjadi modal untuk melakukan kekerasan terhadap anak.

Kekerasan seksual yang yang terjadi termasuk familial abuse. Faktor-faktor yang menyebabkan terjadinya kekerasan seksual yang dialami oleh subjek adalah faktor kesempatan, faktor kelalaian orang tua atau ibu dan faktor ekonomi. Ibu bekerja dan jarang berkomunikasi dengan subjek.

Dampak psikologis yang dialami oleh subjek dapat digolongkan menjadi tiga bagian yaitu gangguan perilaku kognisi, gangguan perilaku dan gangguan emosional. 
a) Gangguan kognisi, ditunjukkan dari subjek mempunyai prasangka dan melaksanakan proses belajar sosial. Setelah ibu menikah subjek telah mempunyai pemikiran bahwa ayah tiri telah menunjukkan tingkah laku yang mencurigakan, terutama saat menatap dirinya.

b) Gangguan perilaku, ditunjukkan dari menjadi lebih pendiam, mudah tersinggung, menyakiti diri sendiri, suka menyendiri, merasa tidak berharga dan menjauh dari teman-teman.

c) Gangguan emosional, ditunjukkan dari depresi, mengisolasikan diri, sensitif dan muda marah

Kekerasan seksual dilakukan oleh ayah tiri sebanyak 2 kali dan semua terjadi di kamar rumah sendiri. Kejadian pertama pada malam hari saat subjek sedang tidur dan yang kedua pada siang hari saat ibu subjek bekerja. Kekerasan yang terjadi antara pertama dan kedua, yaitu meraba bagian dada dan paha.

Dampak setelah mengalami kekerasan seksual subjek mengalami perubahan perilaku, menjadi lebih pendiam, mudah tersinggung, menyakiti diri sendiri, suka menyendiri, merasa tidak berharga dan menjauh dari teman-teman. Fungsi kognitif pada subjek terjadi saat pulang ke rumah ibu dan ayah tirinya, dikarenakan saat dirumah nenek sering bertengkar dengan kakaknya, sehingga memutuskan kembali bersama ibunya. Setelah kembali, subjek sudah mempunyai prasangka terhadap ayah tirinya.

\section{DISKUSI}

Setelah mengalami kekerasan seksual subjek mengalami perubahan perilaku, menjadi lebih pendiam, mudah tersinggung, menyakiti diri sendiri, suka menyendiri, merasa tidak berharga dan menjauh dari teman-teman. Hal ini merupakan dampak dari kekerasan seksual yang dialami, menurut Zastrow (dalam Huraerah,2006) ciri-ciri anak yang mengalami kekerasan seksual memunculkan tanda-tanda perilaku perubahan mendadak seperti dari bahagia menjadi depresi, dari bersahabat menjadi tertutup, menjadi sensitif dan gampang marah. 
Kekerasan seksual yang terjadi termasuk familial abuse. Menurut Noviana (2015) familial abuse yaitu kekerasan seksual dengan pelaku anggota keluarga korban, atau masih terdapat hubungan darah antara pelaku dan korban yaitu ayah tiri. Menurut Finkel (dalam Hayinah, 2019) kekerasan seksual pada anak yang dilakukan oleh kerabat dekat atau anggota keluarga sering disebut incest yang merupakan sebuah tindakan eksploitasi seksual pada anak dibawah 16 tahun oleh orang - orang terdekat atau keluarga. Dalam kasus tersebut, biasanya antara ayah tiri dan anak jarang sekali terjadi atas dasar suka sama suka, dan biasanya yang terjadi atas dasar pemaksaan sehingga terjadi proses kekerasan seksual yang terhadap anak. Pada penelitian ini terjadinya kekerasan yang dilakukan dikarenakan menggunakan kesempatan dan pemaksaan untuk dilayani, subjek tidak mempunyai kekuatan untuk melawan dan hanya bisa terdiam dalam kondisi tertekan.

Faktor-faktor yang menyebabkan terjadinya kekerasan seksual yang dialami oleh subjek adalah faktor kesempatan, subjek tidur malam, ibu sedang bekerja di luar, ayah tiri sedang tidak bekerja, dan kamar tidur tidak mempunyai pintu. Dalam kondisi seperti dimanfaatkan oleh ayah tiri untuk melancarkan aksinya untuk melakukan kekerasan seksual terhadap anak tirinya tersebut. Kesempatan seperti ini biasanya tidak pernah dilewatkan oleh predator anak, sehingga dengan mudah baginya untuk melaksanakan keinginannya tersebut.

Faktor kelalaian orang tua atau ibu, menjadi faktor selanjutnya. Dalam hal ini ibu, tidak memperhatikan perkembangan subjek, jarang berkomunikasi dengan subjek. Walaupun sudah terdapat perubahan perilaku, ibu tidak peka dengan kondisi tersebut. Faktor ekonomi, Ibu bekerja dan jarang berkomunikasi dengan subjek. Ibu subjek harus bekerja baik sebagai buruh nyuci gosok ataupun juga membantu memasak tetangga yang mempunyai usaha kuliner, dengan kondisi ini subjek mempunyai kesulitan untuk menyampaikan apa yang dilakukan ayah tiri terhadap dirinya, selain itu, subjek tidak mempunyai kesempatan untuk bercerita.

Faktor-faktor penyebab selain di atas adalah sesuai dengan teori Richar (dalam Hurairah, 2012) yaitu stress sosial, struktur keluarga dan tipe-tipe keluarga. Stress sosial terjadi pada subjek, dikarena 
sejak awal ibunya menikah sudah mempunyai prasangka terhadap ayah tirinya, yang menyebabkan menyambil keputusan untuk tinggal bersama dengan nenek, akan tetapi di tempat tersebut sering bertengkar dengan kakaknya. Tipe keluarga subjek adalah tipe yang anggota keluarga sibuk dengan pekerjaan masing-masing dan tidak perduli antara satu anggota keluarga dengan yang lainnya. Hal ini ditunjukan oleh ketidak tahuan ibu subjek tentang perbuatan suami terhadap anaknya yaitu subjek.

Dampak psikologis yang dialami oleh subjek dapat digolongkan menjadi tiga bagian yaitu gangguan perilaku kognisi, gangguan perilaku dan gangguan emosional. Gangguan kognisi, ditunjukkan dari subjek mempunyai prasangka dan melaksanakan proses belajar sosial. Setelah ibu menikah subjek telah mempunyai pemikiran bahwa ayah tiri telah meunjukkan tingkah laku yang mencurigakan, terutama saat menatap dirinya. Gangguan perilaku, ditunjukkan dari subjek menjadi lebih pendiam, mudah tersinggung, menyakiti diri sendiri, suka menyendiri, merasa tidak berharga dan menjauh dari teman-teman. Gangguan emosional, ditunjukkan dari depresi, mengisolasikan diri, sensitif dan muda marah. Dinamika psikologi anak perempuan korban kekerasan seksual incest dapat dilihat pada bagan di bawah ini: 
Faktor internal

1. Karakter Anak yang pendiam dan pasrah

2. Terpaksa kembali ke rumah ibu karena sering bertengkar dengan kakak saat di rumah nenek

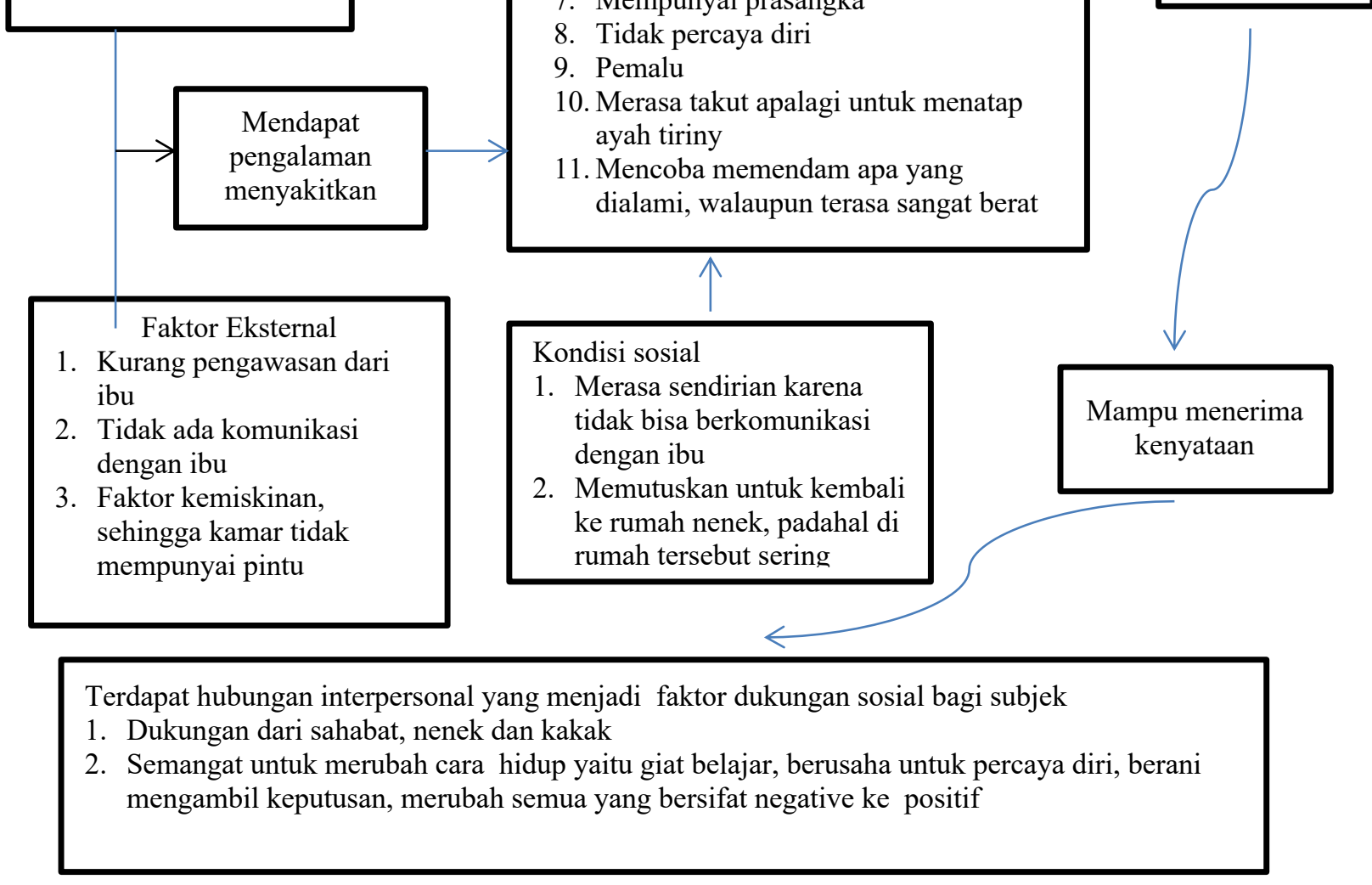

\section{Gambar 1. Ilustrasi Dinamika Psikologis Anak Korban Kekerasan Seksual Incest}

Berdasarkan gambaran tersebut di atas dapat dijelaskan bahwa dinamika psikologis anak perempuan korban kekerasan seksual incest memiliki pola yang sama, berawal dari faktor internal dan faktor eksternal dari subjek. Faktor internal yaitu Karakter Anak yang pendiam dan pasrah serta terpaksa kembali ke rumah ibu karena sering bertengkar dengan kakak saat di rumah nenek. Untuk faktor eksternal kurang pengawasan dan perhatian dari ibu, komunikasi terhambat karena ibu sibuk bekerja, dan terdapat faktor kemiskinan, sehingga ayah tiri dengan mudah dan lancer untuk menjalankan aktifitas kekerasan seksual. 
Peristiwa yang dialami membat subjek menjadi mempunyai pegalaman yang menyakitkan, sehingga menimbulkan dampak psikologis berupa mudah tersinggung, menyakiti diri sendiri, merasa tidak berharga, suka menyendiri, pendiam, menyalahkan diri sendiri, berprasangka, tidak percaya diri, pemalu, merasa takut apalagi menatap mata ayah tirinya, namun demikian masih tetap memendam perasaan yang sangat berat dan harus dihadapi.

Aspek psikologis dengan kondisi sosial seperti merasa sendirian, kembali ke rumah nenek adalah sebagai bukti bahwa subjek belum mampu menerima kenyataan yang menyakitkan tersebut. Namun setelah mendapat dukungan dari sahabat, nenek dan kakak membuat subjek belajar untuk bisa menerima kenyataan sehingga dapat mengambil keputusan untuk kembali ke rumah nenek, walaupun sebetulnya berat karena di rumah nenek subjek sering bertengkat dengan kakaknya. Dengan munculnya sikap dapat menerima kenyataan yang menyakitkan, membuat subjek

Antara aspek kognitif, aspek emosi dan hubungan interpersonal saling mempunyai keterkaitan satu sama lainnya. Sehingga membentuk prilaku yang pendiam, menjadi takut ayah dan takut untuk melakukan komunikasi dengan ibu. Kurangnya komunikasi dengan ibu menyebabkan tidak diketahui penyebab mengapa subjek memutuskan untuk tinggal bersama dengan neneknya kembali.

Fungsi kognitif pada subjek terjadi saat pulang ke rumah ibu dan ayah tirinya, dikarenakan saat dirumah nenek sering bertengkar dengan kakaknya, sehingga memutuskan kembali bersama ibunya. Setelah kembali, subjek sudah mempunyai prasangka terhadap ayah tirinya. Menurut Barron dan Branscombe (2015), prasangka respon emosional negatif yang didasarkan pada keanggotaan kelompok. Sedangkan prasangka menurut Rahman (2017) prasangka adalah penilaian tidak adil terhadap suatu kelompok berdasarkan karakteristik anggota dari kelompok tersebut, nyata atau tidak nata. Prasangka dalam kognitif adalah suatu evaluasi seseorang atau kelompok yang mendasarkan diri pada lingkungan agar nantinya diterima dilingkungan kelompoknya, dalam hal ini diterima oleh ibu subjek. Selain itu prasangka mengarah pada evaluasi negatif walaupun stereotype merupakan hal 
yang dapat bersifat positif disamping dapat negatif. Prasangka terdapat pada subjek karena setiap ayah tiri menatap matanya sudah ada tanda-tanda yang mencurigakan, yang memperkuat prasangka yang dimiliki, sehingga membuat tidak nyaman dan tidak tenang.

Selain itu, terdapat proses belajar yang dimiliki, hal ini ditunjukkan ketika terjadi pelecehan seksual yang kedua, subjek hanya diam karena khawatir jika memberontak ayah tiri akan melakukan yang lebih bahaya dari yang sebelumnya, karena faktor ingatan dari proses learning retention dan remembering sangat berperan, ternyata benar bahwa yang dilakukan ayah tiri adalah meraba paha dan bagian dadanya. Belajar sosial terjadi melalui model atau contoh. Seperti halnya sikap, merupakan hal yang terbentuk melalui proses belajar (Kartono, 1996)

Fungsi emosi, menurut Crow \& Crow (dalam Sobur, 2003) mengartikan emosi sebagai suatu keadaan yang bergejolak pada diri individu yang berfungsi sebagai inner adjustment (penyesuaian dari dalam) terhadap lingkungan untuk mencapai kesejahteraan dan keselamatan individu. Menurut Hude (2006), emosi adalah suatu gejala psikofisologis yang menimbulkan efek pada persepsi, sikap, dan tingkah laku. Pada subjek, fungsi ini terjadi secara harmonis dengan fungsi kognitif.

Pada subjek, fungsi emosi ditunjukkan perasaan dicintai, mencintai membuat menjadi mengerti bahwa ada orang yang menyayangi dirinya disaat senang maupun sedih. Rasa bangga terhadap diri sendiri menunjukkan adanya rasa cinta terhadap dirinya sendiri, walaupun di saatsaat tertentu subjek merasa tidak percaya diri karena malu pada keadaan tertentu, kemandirian menunjukkan bahwa masih mampu dan mau melakukan aktivitas, dipenuhi dengan harapan, keyakinan dan kepercayaan menunjukkan bahwa subjek adalah pribadi yang optimis, dimana dirinya memiliki cita - cita, harapan serta mengetahui cara untuk meraih cita - cita tersebut, hal ini menunjukkan bahwa subjek memiliki pandangan dan tujuan dalam hidupnya setelah mengalami kekerasan seksual.

Proses yang dijalani untuk kembali bangkit dan bersemangat, berlangsung setelah beberapa bulan dari kejadian dan dua bulan dari subjek menceritakan masalahnya, peran sahabat yang selalu 
memberikan dukungan dan semangat membuat subjek berusaha untuk berubah menjadi lebih baik, subjek ingin menjadi pribadi yang lebih baik dan menjaga diri lebih baik, dan mengikuti kegiatan ekstrakulikuler kerohanian Islam di sekolah, sehingga subjek merasa lebih mendekatkan diri kepada Allah.

Subjek berusaha untuk merubah diri menjadi tidak pemalu, belajar menjadi percaya diri, dan belajar untuk mandiri. Dari semua yang telah dilakukan subjek terhadap dirinya merupakan perubahan yang lebih baik dari dalam diri, subjek lebih bersyukur karena mempunyai keyakinan bahwa banyak diluar sana anak yang tidak seberuntung seperti dirinya, sehingga membuat subjek bersyukur, dan berharap kejadian ini tidak terulang lagi, merasa lebih bangga terhadp diri sendiri, merasa bahwa dirinya sudah sangat kuat, sehingga bangga kepada diri sendiri, menilai semua permasalahan yang telah dialami menjadikan sebagai pelajaran, hal ini menandakan bahwa subjek mampu melaksanakan fungsi dari dinamika psikologis, yaitu fungsi kognitif, fungsi emosi dan hubungan interpersonal.

Subjek mempunyai dukungan sosial dari sahabat, serta memiliki keinginan untuk berubah dan membuat kakak, bibi dan nenek subjek berbahagia, bahkan memiliki cita - cita dan berusaha untuk belajar, merasa bahwa dirinya anak yang pintar dibidang matematika, dan memiliki suara yang bagus, subjek juga ingin mengubah sesuatu dari dirinya, yaitu menjadi memiliki kepercayaan, menjadi tidak pemalu, dan juga mengetahui bagaimana cara untuk merubah sifatnya, dari yang negatif ke hal-hal yang positif.

\section{KESIMPULAN DAN SARAN}

Berdasarkan pembahasan di atas maka dapat disimpulkan bahwa kekerasan terjadi disebabkan terdapat faktor ekstrenal dan faktor internal. Akibanya anak perempuan korban kekerasan seksual incest mempunyai dampak psikologi berupa Mudah tersinggung, Menyakiti diri sendiri, Merasa tidak berharga, suka menyendiri, pendiam, menyalahkan diri sendiri, mempunyai prasangka, tidak percaya 
diri, pemalu, merasa takut apalagi untuk menatap ayah tirinya, mencoba memendam apa yang dialami walaupun terasa sangat berat (menutup diri).

Dinamika psikologis anak perempuan korban kekerasan seksual incest memiliki pola yang hamper sama, berawal dari faktor internal dan faktor eksternal dari subjek. Faktor internal yaitu Karakter Anak yang pendiam dan pasrah serta terpaksa kembali ke rumah ibu karena sering bertengkar dengan kakak saat di rumah nenek. Untuk faktor eksternal kurang pengawasan dan perhatian dari ibu, komunikasi terhambat karena ibu sibuk bekerja, dan terdapat faktor kemiskinan, sehingga ayah tiri dengan mudah dan lancar untuk menjalankan aktifitas kekerasan seksual. Dengan keterkaitan kondisi sosial dengan faktor eksternal dan internal membuat subjek sulit menerima kenyataan, sehingga muncul pengalaman yang menyakitkan dengan munculnya aspek psikologis. Sedangkan adanya hubungan antara aspek psikologis dengan faktor kondisi sosial membuat sulit menerima kenyataan, namun dengan adanya dukungan sosial yang diberikan oleh teman, kakak dan nenek, dapat membuat subjek dapat menerima kenyataan dengan cara berperilaku positif dan giat belajar serta aktifitas positif lainnya. Dan pada akhirnya aspek kognitif, aspek emosi dan aspek hubungan interpersonal dapat berjalan dengan baik.

Bagi orang tua tunggal terutama ibu yang mempunyai anak perempuan yang tinggal bersama, sebisa mungkin memberi pengawasan yang ketat dan jangan sampai terjadi pengabaian, dikarenakan pelaku kekerasan seksual terhadap anak adalah orang-orang terdekat yang dengan mudah untuk melancarkan aksinya. Kemiskinan bukan jadi alasan untuk terjadinya kekerasan, jika semua dapat dikomunikasi dengan baik, oleh karena itu sebaiknya di dalam keluarga hendaknya melakukan komunikasi yang efektif. Dengan demikian ketika terjadi kekerasan pada anak, anak dengan mudah menyampaikan apa yang terjadi pada dirinya dan tanpa alasan kesibukan dari pihak orang tua. Selain itu, sebagai orang tua harus lebih peka dengan adanya perubahan-perubahan perilaku dan emosi pada anak, karena dapat dipastikan terdapat peristiwa yang tidak bisa diterima oleh anak. Sehingga disarankan jika melakukan penelitian tentang kekerasan seksual terhadap anak sangat diperlukan 
keterampilan dalam menggali informasi, dan tentunya harus diawali dengan membangun rapport dengan subjek, sehingga semua informasi terkait dengan subjek bisa didapatkan semuanya.

\section{DAFTAR PUSTAKA}

Sobur, Alex. (2003). Semiotika Komunikasi Remaja Rosdakarya. Bandung: Aksara

Arfiana, Muzdalifa. (2018). Upaya Pencegahan Kekerasan Seksual Terhadap Anak Oleh Pelayanan Terpadu Perempuan Dan Anak Surakarta (PTPAS). Surakarta

Baron, Robert \& Branscombe, Nyla. (2015). Psikologi Sosial Jilid 1 Edisi ketiga belas. Jakarta: Erlangga

Cresswell, John. (2014). Research Design Pendekatan Kualitatif, Kuantitatif, dan Mixed, Edisi Ketiga. Yogyakarta: Pustaka Pelajar

Hikmah, Siti. (2017). Mengantisipasi Kejahatan Seksual Terhadap Anak Melalui Pembelajaran "Aku Anak Berani Melindungi Diri Sendiri: Studi Di Yayasan Al-Hikmah Grobogan. Jurnal Sawwa, 12(2), 187-206.

Hude, Darwis. (2006). Emosi. Jakarta: Erlangga

Huraerah, Abu. (2012). Kekerasan Terhadap Anak. Edisi Ketiga. Bandung: Nuansah Cendekia

Komisi Perlindungan Anak Indonesia. (2018). Undang-undang Nomor 35 Tahun 2014 Junto Undang-undang Nomor 23 tahun 2002 tentang Perlindungan Anak. Jakarta: KPAI

Noviana. (2015). Kekerasan Seksual Terhadap Anak: Dampak Dan Penanganannya. Jakarta: Sosio Informa

Rahman, Agus Abdilla (2017). Psikologi Sosial Integrasi Pengetahuan Wahyu dan Pengetahuan Empirik. Jakarta: Rajawali Press

Sugiyono. (2018). Metode Penelitian Kuantitaif, Kualitatif dan $R \& D$. Bandung: Alfabeta

Uyun, Z. (2015). Kekerasan Seksual Pada Anak: Stres Pasca Trauma. Surakarta: Universitas Muhammadiyah Surakarta

Walgito, Bimo. (2017). Pengantar Psikologi Umum. Yogyakarta: Penerbit Andi 